\title{
The Mutation Profiles of KRAS and BRAF Genes in a Romanian Colorectal Cancer Cohort
}

\author{
COSTEL BRINZAN ${ }^{1,2}$, MARIANA ASCHIE ${ }^{1,2}$, CATALIN NICOLAE GRASA ${ }^{2}$, ANCA FLORENTINA MITROI ${ }^{1,2}$, ELENA MATEI ${ }^{1}$, \\ GEORGETA CAMELIA COZARU ${ }^{1,2 *}$ \\ ${ }^{1}$ Ovidius University of Constana, CEDMOG, 145 Tomis Blvd, 900591, Constana, Romania \\ ${ }^{2}$ Clinical Emergency County Hospital of Constana, 145 Tomis Blvd, 900591, Constana, Romania
}

\begin{abstract}
Colorectal cancer $(C R C)$ is one of most commonly diagnosed malignancies and management of CRC differs in according with patient's characteristics, tumortype, differentiation, metastatic extension and KRAS/ $B R A F$ mutations. Based on this knowledge, we examined the relationship between KRAS/BRAF mutations in paraffin-embedded tumor specimens and some clinicopathological features at CRC in order to provide reliable results to the oncologists and so to contribute to the best care provided to the patients. A 56 of colorectal cancer samples were analyzed for the KRAS and BRAF mutational status using StripAssay method from ViennaLab, Austria. Assays for identification of KRAS/BRAF mutations were based on polymerase chain reaction (PCR) and reverse-hybridization. KRAS mutations were present in $50 \%$ (28 patients) of all analyzed CRC and were located in codons 12, 13 and 61. The most frequent types of mutations were substitution of glycine to valine in codon 12 (c.35G $>T ; 9 / 28)$, followed by glycine to aspartate on codon 13 (c.38G >A; 5/28). BRAF mutations were detected at 9 patients (16\%) and in all cases Val600Glu mutation has been observed. In one case we reported a concomitant KRAS/BRAF mutation. According with current data, KRAS and BRAF mutations are associated with a poor patient prognosis in CRC, but KRAS mutation in codon 13 and BRAF appear to have a higher oncogenic potential.
\end{abstract}

Keywords: colorectal cancer, KRAS, BRAF, mutation, genotype

Colorectal cancer (CRC) is the third most common cancer worldwide accounting for over $9 \%$ of all cancer incidences [1, 2]. In Romania CRC is the second most common type of cancer, accounting for $13.3 \%$ of all malignancies in men, and $12.6 \%$ in women [1]. Average survival of patients with metastases was improved by introduction of anti-EGFR therapy with monoclonal antibodies (Cetuximab and Panitumumab) or small molecules of tyrosine kinase inhibitors (Gefitinib and Erlotinib). Since these agents are only effective in certain subset of patients treated, thus identification and characterization of molecular markers to predict tumor response have been an area of interest. CRC patients with KRAS mutations appear to be relative resistant to treatment with monoclonal antibodies, with lower response rates and poorer survival [3-5]. Ras is a proto-oncogene subfamily that encoding low molecular weight GTP-ase proteins of $21 \mathrm{kDa}$. Ras proteins are involved in transducing of cellular signals through mitogen activated protein kinase (MAPK) pathway and acts as on-off switch at intersection of multiple upstream signals. Ras molecules play an important role in carcinogenesis processes, and also are involved in fundamental processes such as cell proliferation, differentiation, survival, invasion, and motility [5]. Most common mutant isoform is $\mathrm{v}$-Ki-ras2 Kristensen rat sarcoma viral oncogene homolog (KRAS), which is present in $22 \%$ of all human cancers [3]. Identification of KRAS mutations was observed in $35-40 \%$ of sporadic CRC cases and over $80 \%$ of this were somatic point mutation detected in codon 12 and 13 of exon 2, and less often in codon 61 $[3,6]$. The v-Raf murine sarcoma viral oncogene homolog B1 (BRAF) gene belongs to RAF (Rapidly Accelerated Fibrosarcoma) family, and has a pivotal role in tumorigenesis [6-8]. The BRAF gene encode cytoplasmic serine/threonine kinase, which play a major role in cell proliferation, survival, differentiation and interfere indirectly with carcinogenesis by constitutive activation of MAPK proliferation pathway in absence of EGFR signals $[9,10]$. BRAF gene is located on long arm of chromosome 7 (7q34) and has been identified as mutagenic target in cancers such as colorectal, thyroid, gastric, lung or non-Hodgkin's lymphomas. The most common BRAF mutation, found in over $90 \%$ of cases it is a unique substitution, of glutamic acid with valine in codon 600 of exon 15 (V600E) [10,11]. Management of CRC, differs in according with patient's characteristics, tumor type, differentiation, metastatic extension and KRAS/BRAF mutations [12,13].

Although there are many articles that address the role of RAS family mutations in colorectal cancer, there are not many published data about KRAS and BRAF mutations in CRC patients in the Romanian population. The aim of this paper is to highlight the profile of KRAS/BRAF gene mutations in patients diagnosed with colorectal cancer and to make genotype-phenotype correlations that can be useful in assessing prognosis at CRC patients.

\section{Experimental part \\ Material and methods}

Cases were selected from the Pathology Department from Clinical Emergency County Hospital in Constanta, Romania. For all analyses, formalin-fixed and paraffinembedded (FFPE) tissue specimens were used. Fifty-six specimens were processed and diagnosed primarily by an experimented pathologistaccording to standard protocols. The histological grade of cancer was classified using the tumors, node, and metastasis (TNM) staging system of the American J oint Committee on Cancer (AI CC) and the International Union Against Cancer (UICC), according to the standard of the World Health Organization (WHO). Clinical information was substracted from medical records and pathology reports including sex, age at diagnosis, histological subtypes of adenocarcinoma, TNM stage, and 
tumor differentiation was collected. Genetic tests were performed within Centre for Research and Development of Morphological and Genetic Studies of Malignant Pathology (CEDMOG), "Ovidius" University of Constanta. Informed consents for mutations testing were signed by all patients.

For DNA isolation, tissue areas up to $250 \mathrm{~mm}^{2}$, and up to eight sections with a maximum thickness of 8 im were used for each case. Hematoxylin and eosin (H\&E) sections were used as a reference and the largest tumor area (at least $50 \%$ tumor cells) was scraped off with a scalpel under a dissecting microscope. Genomic DNA was extracted from FFPE cancer tissues by using QIAamp DNA FFPE Tissue Kit (QIAGEN, Germany) according to the manufacturer's protocol. Isolation and purification of DNA derived from FFPE tissues is accomplished in several steps. The first step was deparaffinization of sections by incubation for $10 \mathrm{~min}$ in xylene and then washes once in absolute ethanol for $10 \mathrm{~min}$ at room temperature. After air drying for 5 minutes at $37^{\circ} \mathrm{C}$, tissue sections were completely lysed in presence of proteinase $K$ and ATL lysis buffer at a temperature of $56^{\circ} \mathrm{C}$ on a heating block for 2-3 hours. In second stage, cell lysate was loaded into QIAamp MinElute column placed in an appropriate collection tube and contaminants were removed by centrifugation, using AW 1 and AW 2 wash solutions. Elution of DNA from silicon membrane was performed with an AE buffer.

\section{KRAS and BRAF mutations analysis}

Method for detecting KRAS and BRAF mutations were based on PCR and reverse-hybridization (StripAssay ViennaLab, Austria), and was performed according with manufacturer's instructions. Assay for the identification of KRAS mutations (KRAS XL StripAssay ${ }^{\circledR}$ ) covers 29 mutations in the KRAS gene (codon 12, 13, 59, 60, 61, 117 and 146), respectively the assay for BRAF mutations (BRAF $600 / 601$ StripAssay ${ }^{\circledR}$ ) covers 9 mutations in the BRAF gene (codon 600 and 601). Procedure includes a PCR amplification step of isolated DNA using biotinylated primers, and a hybridizing step of amplification products to a nitrocellulose strip containing specific allele oligonucleotide probes immobilized as an array of parallel lines. Detection of biotinylated sequences was done using streptavidin-alkaline phosphatase and a chromogenic substrate.

\section{Statistical analysis}

Results obtained were statistical analysed using SPSS version 20 software (SPSS, USA). Pearson's correlations were used to determine associations between KRAS/BRAF genes mutation and clinicopathological features. All $p$ values below 0.05 were considered statistically significant being calculated by $\chi^{2}$ test and paired samples t-test.

\section{Results and discussions}

Some studies have reported significant differences between the KRAS/BRAF genotypes and clinicopathological features such as age, gender, tumor location, histopathology, metastasis and tumor grade, while other studies observed no significant effects [14-16]. Among 56 patients included in our study, 28 patients $(48.20 \%)$ were males and 29 patients (51.80\%) were females, their ages ranged between 40 years and 88 years with an age media of 64.89 years. Clinicopathological features at CRC patients and distribution of KRAS/BRAF genes mutation are presented in table 1.

There were no significant differences in the frequency of KRAS mutations based on gender (14 KRAS mutated female vs. 14 KRAS mutated male). The KRAS mutation frequencies in European, Asian, and Latin American CRC patients were reported to be $36 \%, 24.0 \%$, and $40.0 \%$, respectively $[1,7,8,17]$. In our study, we observed a KRAS mutation rate of $50.00 \%$ in colorectal cancers, being a slightly higher frequency than the European average reported in other studies. However, it should be noted that our study sample size was small to draw meaningful

Table 1

CORRELATIONS BETWEEN KRAS/BRAF MUTATION AND CLINICOPATHOLOGICAL FEATURES IN CRC PATIENTS

\begin{tabular}{|c|c|c|c|c|c|c|}
\hline $\begin{array}{c}\text { Variables/ } \\
\text { Number'percent } \\
(\%)\end{array}$ & $\begin{array}{l}\text { KRAS } \\
\text { Mutant } \\
(\mathbf{n}=28)\end{array}$ & $\begin{array}{c}\text { KRAS } \\
\text { Wild-type } \\
(\mathrm{n}=\mathbf{2 8})\end{array}$ & $\begin{array}{l}\text { H-value } \\
\left(\gamma^{2} \text {-test }\right)\end{array}$ & $\begin{array}{c}\text { BKAF Mutant } \\
(n=9)\end{array}$ & $\begin{array}{c}\text { BRAF } \\
\text { Wild-type } \\
(\mathbf{n}=47)\end{array}$ & $\begin{array}{l}\text { p-value } \\
\text { (Paired } \\
\text { samples } \\
\text { t-tesi) }\end{array}$ \\
\hline \multicolumn{7}{|l|}{ Sex } \\
\hline Male & $14(25.00)$ & $13(23.20)$ & \multirow[t]{3}{*}{$\approx 0.001^{\circ+}$} & $3(5.35 \%)$ & $28(50.00)$ & \multirow[t]{3}{*}{0.32} \\
\hline Female & $.4(25.00)$ & $15(26.80)$ & & $6(10.71 \%)$ & $19(33.93)$ & \\
\hline $\begin{array}{l}\text { p-value } \\
\text { ( } \mathrm{z}^{2} \text {-test) }\end{array}$ & 070 & 025 & & 031 & 218 & \\
\hline \multicolumn{7}{|l|}{ Age } \\
\hline$\leq 65$ & $15(.678)$ & $11(1964)$ & \multirow[t]{3}{*}{093} & $1(179)$ & $74(42.26)$ & \multirow[t]{3}{*}{079} \\
\hline$=65$ & $13(33.22)$ & $17(30.36)$ & & $8(14.28)$ & $23(41.07 \%)$ & \\
\hline $\begin{array}{r}\text { p-value } \\
\left({ }^{2} \text {-test }\right)\end{array}$ & 1.00 & 0.70 & & $0.02^{\circ}$ & J.88 & \\
\hline \multicolumn{2}{|l|}{ Tumor location } & $11(19.64)$ & & $3(5.36)$ & $17(30.36)$ & \multirow{4}{*}{0.51} \\
\hline Distal colon & $10(17.86)$ & $10(17.86)$ & \multirow[t]{3}{*}{0.74} & $5(8.93)$ & $15(26.78)$ & \\
\hline Rectum & $9(15.07)$ & $7(12.50)$ & & $1(1.79)$ & $15(26.78)$ & \\
\hline $\begin{array}{r}\text { p-value } \\
\left(\mathrm{z}^{3} \text {-test }\right)\end{array}$ & 096 & 0.62 & & 0.25 & 0.91 & \\
\hline \multicolumn{7}{|l|}{ Histological type } \\
\hline Adenocarcinoma & $14(25.0)$ & $18(32.10)$ & \multirow[t]{3}{*}{0.11} & $2(3.60)$ & $30(53.50)$ & \multirow[t]{3}{*}{0.35} \\
\hline Other carcinuma" & $14(25.0)$ & $10(17.90)$ & & $7(12.50)$ & $17(30.40)$ & \\
\hline $\begin{array}{r}\text { p-value } \\
\left(\chi^{2} \text {-test }\right)\end{array}$ & 1.00 & 0.15 & & 0.096 & 0.058 & \\
\hline \multicolumn{7}{|c|}{ Depth of tumor invasion } \\
\hline T1-T2 & $1(1.79)$ & $5(8.92)$ & \multirow[t]{3}{*}{0.63} & $1(1.79)$ & $5(8.93)$ & \multirow[t]{3}{*}{0.10} \\
\hline T3-T4 & $27(48.21)$ & $23(41.08)$ & & $8(14.28)$ & $42(75.00)$ & \\
\hline $\begin{array}{l}\text { p-value } \\
\text { ( } z^{2} \text {-test) }\end{array}$ & $80.001 \%$ & $0.001^{\circ}$ & & $0.02^{\circ}$ & $60.001^{\circ}$ & \\
\hline
\end{tabular}




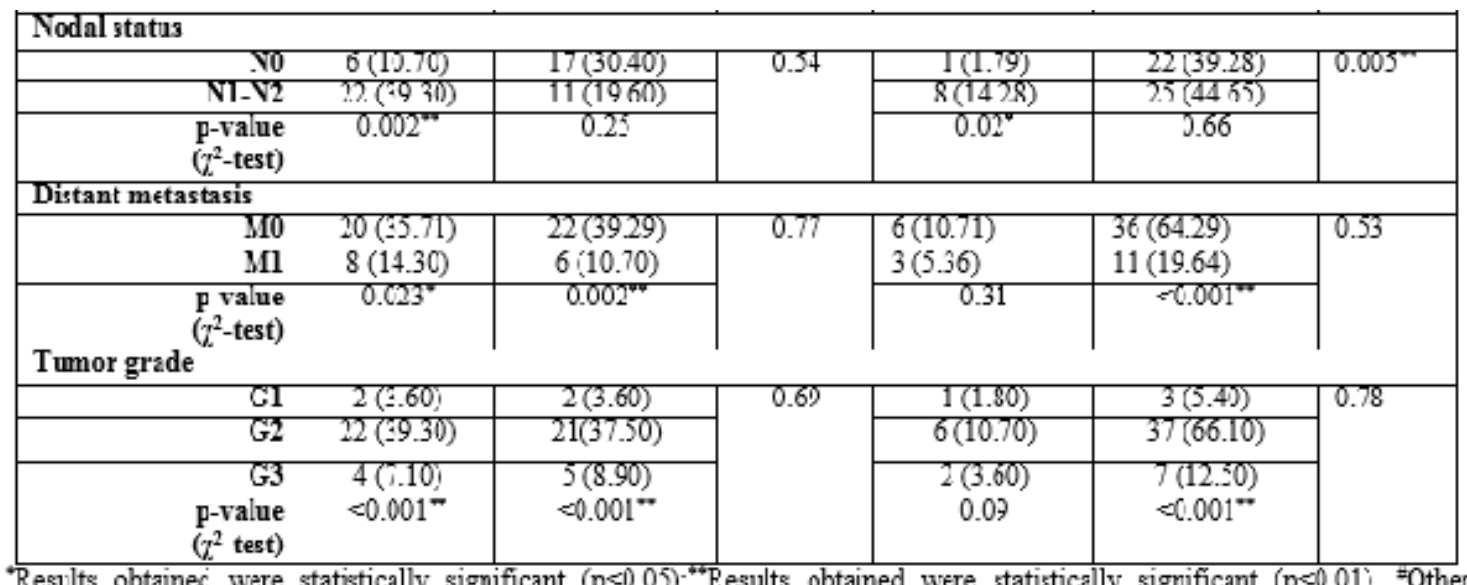

Table 1

CONTINUATED

carcinoma: mucinous adenocarcinoma, signet ring cell, adenosquanous.

conclusions regarding these variations. A total of 9 patients $(16 \%)$ were BRAF mutant, which is in according with previous reports [18-20]. Yaeger R. etal., showed that BRAF mutation confers a poor prognosis in metastatic CRC patients. Frequency of BRAF mutations was higher on female patients than male patients ( $10.71 \%$ vs. $5.36 \%)$ [ 18$]$. Regarding age, KRAS mutations were more common in the age group under 65 years ( $26.78 \%$ vs. $23.22 \%)$, and BRAF mutations in those over 65 years ( $14.28 \%$ vs. $1.79 \%)$. KRAS/BRAF mutations were more commonly found at patients with tumor location in the distal colon. CRC mutant cases had a higher T stage (T3-T4: $48.21 \%$ and $14.28 \%$ vs. T1-T2: $1.79 \%$ and $1.79 \%$ ), more frequently a moderate tumor grade and N1-N2 nodal status (39.30\% vs. $10.70 \%$ for KRAS mutations, respectively $14.28 \%$ vs. $1.79 \%$, for BRAF mutations) without distant metastases (M0-35.71\% vs. M1-14.30\% for KRAS mutations, respectively M0-10.71\% vs. M1-5.36\%, for BRAF mutations).

The distribution of the KRAS/BRAF mutations identified in CRC patients is shown in figure 1 and the correlations KRAS/BRAF genotype and clinicopathological features in table 2.

The genetic basis for the mutation distribution among KRAS and BRAF isoforms gene is not fully understood, but the specialists support the idea that KRAS and BRAF have different roles in complex process of tumorigenesis, and molecular genetic changes may be more accurate markers than clinicopathological features to evaluate the prognosis of cases with early from medium stage in CRC [21-23]. Both KRAS and BRAF mutations are classified as leading

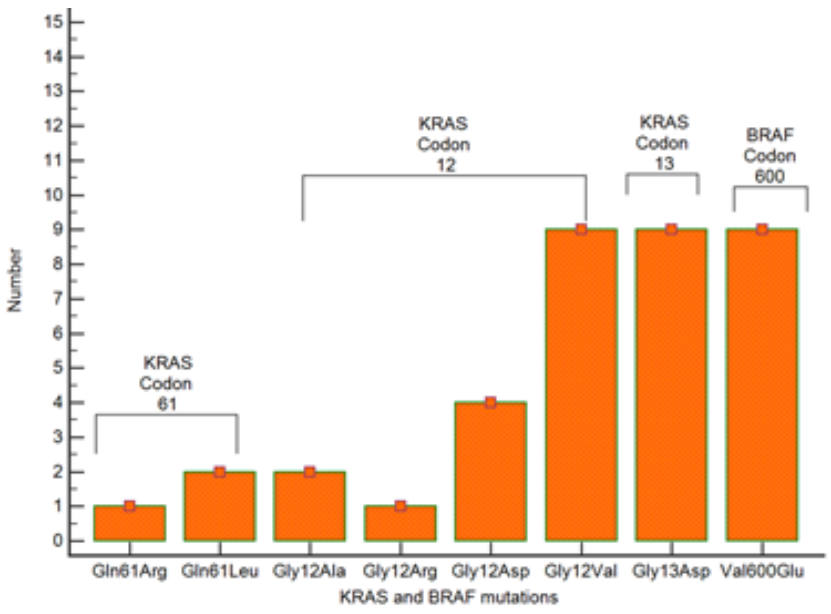

Fig.1. Type of KRAS/BRAF mutations in CRC patients: distribution of the mutant $K R A S(G>T)$ and $(G>C)$ and $(A>T)$ transversions and $\operatorname{KRAS}(\mathrm{G}>\mathrm{A})$ transitions.

mutations, since they are both mutated prior to malignant conversion and are therefore primary genetic events in CRC carcinogenesis [24]. Grimmond et al. (1992), have shown that critical regions of the KRAS gene for activation include codons $12,13,59,61$, and 63 . In a similar study, K. Kimura et al. (2007) [25-26], showed that mutation in KRAS gene is associated with CRC and appear most often in codons $12(28 \%)$, and $13(8 \%)$, and less frequently in codon 61 of exon 2. Distribution of KRAS mutations in our study is similar to the studies mentioned, but their frequency is different, thus: CRC cases have associated

Table 2

CORRELATIONS GENOTYPE-FENOTYPE IN KRAS/BRAF MUTANT CRC

\begin{tabular}{|c|c|c|c|c|c|c|c|c|c|}
\hline \multirow[b]{2}{*}{$\begin{array}{l}\text { Clinico-pathological } \\
\text { features }\end{array}$} & \multicolumn{7}{|c|}{ KRAS mutations } & \multirow{2}{*}{$\begin{array}{c}\begin{array}{c}\text { BRAF } \\
\text { mutations }\end{array} \\
\text { V600E }\end{array}$} & \multirow{2}{*}{$\begin{array}{c}\begin{array}{c}\text { Concomitant } \\
\text { mutations }\end{array} \\
\text { Gl2V (KRAS) } \\
\text { V600E } \\
\text { (BRAF) } \\
\end{array}$} \\
\hline & G12V & G12D & G12A & G12R & G13D & Q61L & Q61R & & \\
\hline \multicolumn{10}{|l|}{ Sex } \\
\hline Male & -0.088 & -0.129 & 0.007 & 0.140 & 0.064 & 0.140 & 0.199 & -0.130 & -0.130 \\
\hline p & 0.521 & 0.344 & 0.960 & 0.304 & 0.638 & 0.304 & 0.141 & 0.338 & 0.339 \\
\hline Female & 0.088 & 0.129 & -0.007 & -0.140 & -0.064 & -0.140 & -0.199 & 0.130 & 0.130 \\
\hline p value & 0.521 & 0.344 & 0.960 & 0.304 & 0.638 & 0.304 & 0.141 & 0.338 & .0339 \\
\hline \multicolumn{10}{|l|}{ Age } \\
\hline$\leq 65$ years & 0.123 & -0.258 & 0.207 & -0.126 & 0.080 & 0.145 & 0.207 & -0.212 & 0.145 \\
\hline $\mathbf{p}$ & 0.334 & 0.055 & 0.126 & 0.357 & 0.557 & 0.287 & 0.126 & 0.116 & 0.287 \\
\hline$>65$ years & -0.132 & 0.258 & -0.207 & 0.126 & -0.080 & -0.145 & -0.207 & 0.212 & -0.145 \\
\hline $\mathbf{p}$ & 0.334 & 0.055 & 0.126 & 0.357 & 0.557 & 0.287 & 0.126 & 0.116 & 0.287 \\
\hline \multicolumn{10}{|l|}{ Tumor location } \\
\hline Proximal colon & -0.198 & 0.083 & 0.258 & -0.101 & -0.022 & -0.101 & -0.143 & -0.022 & 0.181 \\
\hline p & 0.144 & 0.545 & 0.055 & 0.461 & 0.874 & 0.461 & 0.292 & 0.874 & 0.182 \\
\hline Distal colon & -0.091 & 0.083 & -0.143 & 0.181 & 0.080 & -0.101 & 0.057 & 0.181 & -0.101 \\
\hline p & 0.503 & 0.543 & 0.292 & 0.182 & 0.559 & 0.461 & 0.674 & 0.181 & 0.461 \\
\hline Rectum & 0.307 & -0.175 & -0.122 & -0.085 & -0.062 & 0.213 & 0.091 & -0.169 & -0.085 \\
\hline $\mathbf{p}$ & $0.022^{\circ}$ & 0.196 & 0.372 & 0.532 & 0.653 & 0.115 & 0.503 & 0.213 & 0.532 \\
\hline
\end{tabular}




\begin{tabular}{|c|c|c|c|c|c|c|c|c|c|}
\hline \multicolumn{10}{|l|}{ Histological type } \\
\hline Adenocarcinoma & 0.059 & -0.169 & 0.222 & -0.117 & 0.014 & 0.156 & -0.167 & -0.292 & -0.150 \\
\hline p & 0.668 & 0.212 & 0.100 & 0.391 & 0.918 & 0.252 & 0.220 & $0.029^{\circ}$ & 0.269 \\
\hline Other carcinoma & -0.044 & 0.180 & -0.214 & 0.121 & 0.002 & -0.150 & 0.173 & 0.309 & 0.156 \\
\hline p & 0.704 & 0.184 & 0.113 & 0.374 & 0.990 & 0.269 & 0.203 & $0.021^{\circ}$ & 0.252 \\
\hline \multicolumn{10}{|l|}{ Depth of tumor invasion } \\
\hline $\begin{array}{r}\text { T1-T2 } \\
\end{array}$ & 0.024 & -0.096 & -0.067 & -0.047 & -0.152 & -0.047 & -0.067 & 0.006 & -0.047 \\
\hline $\mathbf{p}$ & 0.863 & 0.481 & 0.625 & 0.732 & 0.265 & 0.732 & 0.625 & 0.967 & 0.732 \\
\hline T3-T4 & -0.024 & 0.096 & 0.067 & 0.047 & 0.152 & 0.047 & 0.067 & -0.006 & 0.047 \\
\hline $\mathbf{p}$ & 0.863 & 0.481 & 0.625 & 0.732 & 0.265 & 0.732 & 0.625 & 0.967 & 0.732 \\
\hline \multicolumn{10}{|l|}{ Nodal status } \\
\hline No & -0.224 & 0.061 & 0.239 & 0.168 & -0.352 & -0.108 & -0.155 & -0.252 & -0.108 \\
\hline $\mathbf{p}$ & 0.097 & 0.656 & 0.076 & 0.217 & $0.008^{++}$ & 0.426 & 0.255 & 0.061 & 0.426 \\
\hline $\mathrm{N1-N2}$ & 0.237 & -0.050 & -0.231 & -0.162 & 0.365 & 0.113 & 0.161 & 0.266 & 0.113 \\
\hline $\mathbf{p}$ & 0.079 & 0.713 & 0.087 & 0.234 & $0.006^{\prime \prime}$ & 0.409 & 0.237 & $0.047^{\circ}$ & 0.409 \\
\hline \multicolumn{10}{|l|}{ Distant metastasis } \\
\hline M0 & -0.214 & -0.145 & 0.116 & 0.082 & 0.045 & 0.082 & -0.101 & -0.174 & 0.082 \\
\hline $\mathbf{p}$ & 0.113 & 0.285 & 0.393 & 0.550 & 0.741 & 0.550 & 0.459 & 0.198 & 0.550 \\
\hline M & 0.236 & 0.160 & -0.111 & -0.078 & -0.140 & -0.078 & 0.111 & 0.197 & -0.078 \\
\hline $\mathbf{p}$ & 0.080 & 0.238 & 0.415 & 0.568 & 0.302 & 0.568 & 0.415 & 0.147 & 0.568 \\
\hline \multicolumn{10}{|l|}{ Tumor grade } \\
\hline Gl & -0.097 & -0.066 & -0.046 & 0.567 & -0.104 & -0.032 & -0.046 & 0.112 & -0.032 \\
\hline $\mathbf{p}$ & 0.476 & 0.629 & 0.738 & $<0.001^{+*}$ & 0.445 & 0.814 & 0.738 & 0.412 & 0.814 \\
\hline G2 & -0.017 & -0.012 & 0.106 & -0.245 & 0.010 & 0.074 & 0.106 & -0.105 & 0.074 \\
\hline $\mathbf{p}$ & 0.899 & 0.932 & 0.438 & 0.069 & 0.940 & 0.587 & 0.438 & 0.442 & 0.587 \\
\hline G3 & -0.040 & 0.067 & -0.084 & -0.059 & 0.073 & -0.059 & -0.084 & 0.073 & -0.059 \\
\hline p & 0.771 & 0.621 & 0.537 & 0.666 & 0.591 & 0.666 & 0.537 & 0.591 & 0.666 \\
\hline
\end{tabular}

"Results obtained were statistically significant ( $<<0.05) ;{ }^{*+}$ Results obtained were statistically significant ( $\left.<<0.01\right)$; ${ }^{\circ}$ Other carcinoma: mucinous adenocarcinoma, signet ring cell, adenosquamous.

KRAS mutations in codon 12 in $57.14 \%$ (16/28 cases), codon 13 in $32.14 \%$ ( $9 / 28$ cases), and $10.72 \%$ (3/28 cases) in codon 61 (Fig. 1). Allelic mutations result in aminoacid changes, namely Gly to Asp, Ala, Arg, Ser, Val, or Cys in codon 12 and Gly to Asp in codon 13 that lead to conformational changes in the KRAS protein [16]. In CRC, the main mutation of KRAS is representing by substitution of Gly to Asp and that has been found to occur in codon 12 . Mutation from GGT (Gly) to GTT (Val) in codon 12 has been observed more frequently in primary metastatic of CRC, suggesting that this mutation may confer a more aggressive phenotype $[27,28]$. Compared to these data, the most common mutation found in our study was substitution of glycine to valine in codon 12 (c.35G $>$ T; 9 / 28), followed by glycine to aspartate in codon 13 (c.38G >A; $5 / 28)$, and in the same proportion glycine to aspartate in codon 12, respectively in codon 13 (c.35G>A; 4/28) (fig. $1)$.

The 28 KRAS mutations were equally represented by transitions and transversions. In codon 12, the mutant KRAS $(G>T)$ and $(G>C)$ and $(A>T)$ transversions were the most common mutations, being found in 11 cases, compared to only 4 cases with transitions $(G>A)$. All mutations in codon 13 were transitions $(G>A)$. The $C R C$ with KRAS/ BRAF gene mutations were diagnosed in equal proportions as adenocarcinomas and other carcinomas (mucinous adenocarcinoma, signet ring cell, adenosquamous). In a study published by W. S. Samowitz et al., in 2000 it appears that mutations in codon 13, resulting in the substitution of Gly with Asp, observed in CRC has been shown to be associated with reduced survival rates [29]. Similar to these results, we identified KRAS mutations in codon 13 at patients diagnosed with poorly or moderately differentiated CRC, and one case presented concomitant Gly12Val mutation in codon 12 of the KRAS gene and the Val600Glu mutation in the BRAF gene. Regarding the clinical-pathological features, this case did not differ particularly from the other cases diagnosed with only one type of mutation. Possible mechanism of having coexistent KRAS and BRAF mutation is unknown as its frequency is very low and it is not clear whether or not these tumors have a different biology and natural history than KRAS or BRAF mutant tumors or which of two mutations is dominant oncogene driving tumor proliferation [30]. According with current data, KRAS and BRAF mutations are associated with a poor patient prognosis in CRC [33-34] but BRAF has been shown to be a more potent oncogene than KRAS. In our study, a significant positive correlations were observed between tumor location or nodal status for patients and type of KRAS mutations (Gly12Val, $r=0.307, p<0.05$; Gly13Asp, $(r=0.365, p<0.01)$, while BRAF V600E mutation had a significant positive correlations with advanced stage (N1-N2) of lymph node metastasis $(r=0.266, p<0.05)$ (table 2). However valid conclusions cannot be drawn regarding these findings variations due to the limitations of this study.

\section{Conclusions}

Our preliminary findings suggest a fairly high frequency of KRAS/BRAF mutations in colorectal cancer, but a larger study with sufficient numbers would be required to derive meaningful results to determine whether these variations are valid to make genotype-phenotype correlations in mutant KRAS / BRAF colorectal cancers.

\section{References}

1.ZHANG H.F., XIE Z.R., WANG H.W., XU Y., LIANG R., LU Y.W., LI REN, KONG X.Y., WANG K.H., Int. J. Clin. Exp. Pathol., 9, nr. 2, 2016, p. 20992105.

2.HUMAID 0., AL-SHAMSI, ALHAZZANI W., WOLFF R.A., J. Gastrointest. Oncol., 6, nr. 3, 2015, p. 314-321.

3.BRUERA G., CANNITA K., Di GIACOMO D., LAMY A, TRONCONE G., DAL MAS A. et al., BMC Med., 10, nr.8, 20121, p. 135.

4.DOUILLARD J.Y., OLINER K.S., SIENA S., TABERNERO I ., BURKES R., BARUGEL M. et al., N. Engl. J. Med., 369, nr.11, 2013, p. 1023-1034. 5.SCALTRITI M., BASELGA J., Clinical cancer research: an official journal of the American Association for Cancer Research, 12, 2006, p. 5268-5272, https://doi.org/10.1158/1078-0432.Ccr-05-1554.

6.YOON H.H., TOUGERON D., SHI Q., ALBERTS S.R., MAHONEY M.R., NELSON G.D., et al., Clin. Cancer Res., 20, 2014, p. 3033-3043. 7.YE J.X., LIU Y., QIN Y., ZHONG H.H., YI W.N., SHI X.Y., World J. Gastroenterol., 21, 2015, p.1595-1605.

8.KADOWAKI S., KAKUTA M., TAKAHASHI S., TAKAHASHI A., ARAI Y., NISHIMURA Y., et al., World J. Gastroenterol., 21, 2015, p. 1275-1283. 9.HERZIG D.O., TSIKITIS V.L., J. Surg. Oncol., 111, 2015, p. 96-102. 
10.PAI R.K., JAYACHANDRAN P., KOONG A.C., CHANG D.T., KWOK S., MA L., et al., Am. J. Surg. Pathol., 36, 2012, p. 744-752.

11.CHEN J ., GUO F., SHI X., ZHANG L., ZHANG A., JIN H., et al., BMC Cancer, 14, 2014, p. 802.

12.MINOO P., ZLOBEC I., PETERSON M., TERRACCIANO L., LUGLI A., Int. J. Oncol., 37, 2010, p. 707-718.

13.AHN T.S., JEONG D., SON M.W., JUNG H., PARK S., KIM H., et al., J . Cancer Res. Clin. Oncol., 140, 2014, p. 1863-1871.

14.PROVENZALE D., et al., J ournal of the National Comprehensive Cancer Network, 14, 2016, p. 1010-1030.

15.KIM B., PARK S.J., CHEON J.H., KIM T.I., KIM W.H., HONG S.P., World J. Gastroenterol., 20, 2014, p. 4370-4376.

16.J ANEIK S., DRABEK J., RADZIOCH D., HAJDUCH M., J ournal of Biomedicine and Biotechnology, 2010, https://doi.org/10.1155/2010/ 150960.

17.PHIPPSA.I., etal., British J ournal of Cancer, 108, 2013, p. 1757-1764. 18.YAEGER R., CERCEK A., CHOU J.F., SYLVESTER B.E., KEMENY N.E., HECHTMAN J.F., et al., Cancer, 120, 2014, p. 2316-2324.

19.CLARKE C.N., KOPETZ E.S., J. Gastrointest. Oncol., 6, 2015, p. 660667.

20.EKLOF V., WIKBERG M.L., EDIN S., DAHLIN A.M., JONSSON B.A., OBERG A., et al., Br. J. Cancer., 108, 2013, p. 2153-2163.
21.TOL J., NAGTEGAAL I.D., PUNT C.J ., N. Engl. J. Med., 361, 2009, p. 98-99.

22.EKLOF V., WIKBERG M.L., EDIN S., DAHLIN A.M., JONSSON B.A., OBERG A. et al., Br. J. Cancer, 108, 2013, p. 2153-2163.

23.RENAUD S., ROMAIN B., FALCOZ P.E., OLLAND A., SANTELMO N., BRIGAND C. et al., Br. J. Cancer, 112, 2015, p. 720-728.

24.SIRAJ A.K, BU R., PRABHAKARAN S., BAVI P., BEG S., AL HAZMI M. et al., Mol. Cancer, 13, 2014, p. 168.

25.ROTH A.D., TEJPAR S., DELORENZI M., YAN P., FIOCCA R., KLINGBIEL D. et al., J. Clin. Oncol., 28, 2010, p. 466-474.

26.GRIMMOND S.M., RAGHAVAN D., RUSSELL P. J., Urol. Res., 20, 1992, p. 121-126.

27.AL-MULLA F., GOING J.J., SOWDEN E.T.H.H., J ournal of Pathology, 185, nr. 2, 1998, p. 130-138.

28.PHIPPS A.I., BUCHANAN D.D., MAKAR K.W., W IN A.K., BARON J .A., LINDOR N.M. et al., Br. J. Cancer, 108, 2013, p. 1757-1764.

29.SAMOWITZ W.S., CURTIN K., SCHAFFER D., ROBERTSON M., LEPPERT M., SLATTERY M. L., Cancer Epidemiology Biomarkers and Prevention, 9, nr. 11, 2000, p. 1193-1197.

30.VELHO S. et al., BMC Cancer, 8, 2008, 255.

$\overline{\text { Manuscript received: } 21.08 .2018}$ 